\title{
CHEMICAL DEFENSE IN A MARINE ALGA: HERITABILITY AND THE POTENTIAL FOR SELECTION BY HERBIVORES
}

\author{
J. T. Wright, ${ }^{1,3}$ R. De Nys, ${ }^{2,4}$ A. G. B. Poore, ${ }^{1}$ And P. D. Steinberg ${ }^{2}$ \\ ${ }^{1}$ School of Biological, Earth and Environmental Sciences, University of New South Wales, \\ New South Wales 2052, Australia \\ ${ }^{2}$ Centre for Marine Biofouling and Bio-Innovation, University of New South Wales, New South Wales 2052, Australia
}

\begin{abstract}
Herbivores have major impacts on many marine algae and are assumed to have been important forces driving the evolution of algal chemical defenses. However, an evolutionary change in chemical defenses in response to herbivory requires that there is both heritable variation for that trait and a response by herbivores to such variation. The subtidal red alga Delisea pulchra produces four main secondary metabolites (furanones) that vary in concentration at a variety of spatial and temporal scales. Here we determined the heritability of furanone concentrations and then, with a series of feeding experiments, determined how feeding by herbivores associated with $D$. pulchra varied as a function of nonpolar extract and furanone concentration. Total furanone concentration showed significant broad-sense heritability $\left(h_{\mathrm{C}}^{2}=0.234\right)$, but broad-sense heritability of the four individual furanones varied in magnitude, ranging from 0.058 to 0.321 . Compound 3 , which is often the most abundant furanone, was the only one of the four furanones to show significant genetic variation. However, all four furanones were strongly genetically correlated, indicating that selection acting on any one of them will cause a corresponding change in the others. With the exception of the mesograzer gastropod Phasianotrochus eximius, herbivores generally consumed $D$. pulchra at lower rates compared to other common macroalgae. Macrograzers (sea urchins and large gastropods) were mostly deterred by nonpolar extract that contained levels of furanones that spanned the range of furanone variation in the field. The amphipod Ampithoe ngana was not deterred at the lowest extract concentration, and $P$. eximius was not deterred by any naturally occurring extract concentration. Compound 3 was deterrent to macrograzers at 3 and $5 \mathrm{mg} / \mathrm{g}$ dry mass, but was not deterrent at $1 \mathrm{mg} /$ g dry mass. Compound 3 was also not deterrent to A. ngana at any of those concentrations. For the most part $D$. pulchra in the field contains concentrations of furanones that are strongly deterrent to most herbivores. However, at some places and times, furanones do occur at lower concentrations that are not deterrent to herbivores. Given the heritable variation for furanones, when this overlap occurs there is the potential for selection by herbivores for higher concentrations of furanones in D. pulchra.
\end{abstract}

Key words: chemical defense; Delisea pulchra; feeding deterrence; furanones; herbivores; heritability; marine algae; marine plant-herbivore interactions; natural selection; quantitative genetics.

\section{INTRODUCTION}

The idea that herbivores exert selective pressure on plants is pervasive and underlies many of the theories that attempt to explain plant-herbivore interactions. This assumption is not surprising given the major impact herbivores have in reducing the growth, reproduction, and survivorship of terrestrial and marine plants (Hay and Steinberg 1992, Marquis 1992). Herbivory in marine systems in particular, can be extreme. Tropical marine herbivores, principally fishes, can remove as much as $100 \%$ of daily algal production (Car-

Manuscript received 12 May 2003; revised 20 April 2004; accepted 30 April 2004. Corresponding Editor: K. F. Raffa.

${ }^{3}$ Present address: Institute of Conservation Biology and Department of Biological Science, University of Wollongong, New South Wales 2522, Australia.E-mail: jeffw@uow.edu.au

${ }^{4}$ Present address: School of Marine Biology and Aquaculture, James Cook University, Townsville, Queensland, 4811, Australia. penter 1986). In temperate regions where sea urchins and gastropods are generally the dominant herbivores, grazing is not quite as intense (Hay and Steinberg 1992). Nonetheless, temperate sea urchins can remove all fleshy and foliose algae where they graze and create patches of "barrens" or "deforested" areas (Dean et al. 1984, Fletcher 1987, Andrew 1993). Temperate gastropods (Hawkins and Hartnoll 1983), fishes (Andrew and Jones 1990), and amphipods (Tegner and Dayton 1987, Duffy and Hay 2000) can also have significant impacts on temperate marine plants.

Many terrestrial and marine plants produce secondary metabolites that deter feeding by herbivores (Fritz and Simms 1992, Hay and Steinberg 1992, Rosenthal and Berenbaum 1992, Paul et al. 2001). Generally, it is assumed that these compounds have evolved in response to natural selection by enemies such as herbivores (Erlich and Raven 1964, Futuyma 1983). However, such selection has rarely been demonstrated (see 
Marquis 1992, Rausher 1996). Few studies of terrestrial plants have clearly demonstrated a selective impact by herbivores for different concentrations of secondary metabolites (Mauricio and Rausher 1997, Shonle and Bergelson 2000). Mauricio and Rausher (1997) also demonstrated selection by herbivores for a physical defense (trichome density) and Simms and Rausher (1989) demonstrated selection by herbivores for resistance itself.

For an evolutionary change to occur in response to natural enemies, genetic variation for a resistance trait is required (Simms and Rausher 1992). In many terrestrial plants, quantitative variation in resistance (e.g., Berenbaum et al. 1986, Fritz and Price 1988, Simms and Rausher 1989) and traits that confer resistance (e.g., secondary metabolites and trichomes) have a significant genetic basis (Berenbaum and Zangerl 1992, Mauricio 1998, Hamilton et al. 2001). The degree of genetic control over variation in the concentrations of secondary metabolites differs among species, but heritabilities are generally in the order of 0.5 or greater (Berenbaum and Zangerl 1992, Hamilton et al. 2001). Thus, quantitative variation of many terrestrial plant secondary metabolites is under substantial genetic influence and has the potential to respond to selection by natural enemies.

Marine algae produce secondary metabolites similar to those found in terrestrial plants such as terpenes, acetogenins, and polyphenolics, but they also produce other active secondary metabolites not found in terrestrial plants, such as those that contain halogens (Hay and Steinberg 1992, Paul et al. 2001). Algal secondary metabolites deter a range of natural enemies including herbivores (see Hay and Steinberg 1992, Paul et al. 2001), epiphytes (de Nys et al. 1995, Schmitt et al. 1995), bacteria (Maximilien et al. 1998), and competitors (de Nys et al. 1991). Quantitative variation in the concentrations of algal secondary metabolites is widespread (Van Alstyne et al. 2001) and the variation within populations can be considerable (Wright et al. $2000 b$ ). Importantly, the deterrence of natural enemies of marine algae by secondary metabolites is often concentration dependent (e.g., Hay et al. 1987, Steinberg 1988, de Nys et al. 1995, Schmitt et al. 1995). Of these natural enemies, herbivores are usually considered to have the greatest impact on marine algae, and models for the evolution of algal secondary metabolites generally invoke an important role for resistance to herbivory (Hay and Steinberg 1992, Steinberg 1992).

To date, research examining the factors responsible for quantitative variation in algal secondary metabolites has focused on phenotypic change in response to environmental factors such as nutrients, light, desiccation, or induction due to herbivory (Yates and Peckol 1993, Arnold et al. 1995, Cronin and Hay 1996a, $b$, Puglisi and Paul 1997). There are no studies describing the extent to which quantitative variation in algal secondary metabolites is heritable and only one study demonstrating qualitative inheritance of these compounds (Masuda et al. 1997). Indeed, only one study has examined the heritability of a quantitative defensive trait in a marine organism. Harvell (1998) found significant genetic variation and heritability $>0.64$ for spine length in the bryozoan Membranipora membranacea. The absence of data describing the heritability of algal secondary metabolites represents a major gap in understanding the evolution of these compounds.

In this paper we investigated the potential for the secondary metabolites of a common subtidal red alga to respond to selection (i.e., their heritability) and then, with a series of feeding experiments, the potential for herbivores to impose such selection. Initially, we documented patterns of variation in the secondary metabolites (furanones) from the red alga Delisea pulchra (Greville) Montagne (Bonnemaisoniales, Rhodophyta) and herbivore abundance (macrograzers and mesograzers) at two locations. We then asked the following specific questions (1) Is quantitative variation in furanones from D. pulchra heritable? (2) Are the different furanones genetically correlated (i.e., will selection on one furanone cause a parallel change in the others)? (3) What are the feeding rates of herbivores on $D$. pulchra vs. other common macroalgae? (4) Are nonpolar extracts and the furanone from $D$. pulchra that is often most abundant deterrent to herbivores? (5) Does feeding by herbivores vary with the concentration of nonpolar extract and the furanone from D. pulchra that is often most abundant? If quantitative variation in furanones is heritable, and feeding by herbivores increases with decreasing furanone concentration, then there is the potential for herbivores to impose selection for higher concentrations of these compounds.

\section{Methods}

\section{Study sites and organisms}

Algae and herbivores used in this study were collected primarily from Bare Island, near Sydney, Australia $\left(33^{\circ} 59^{\prime} 32^{\prime \prime} \mathrm{S}, 151^{\circ} 13^{\prime} 50^{\prime \prime} \mathrm{E}\right)$. Sampling of variation in furanones and herbivores associated with $\mathrm{De}$ lisea pulchra was also conducted at nearby Cape Banks $\left(34^{\circ} 00^{\prime} \mathrm{S}, 151^{\circ} 14^{\prime} 33^{\prime \prime} \mathrm{E}\right)$. Some individuals of the sea urchin Holopneustes purpurascens were collected from

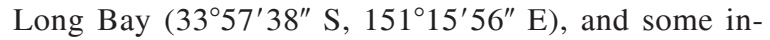
dividuals of the amphipod Ampithoe ngana were collected from Shark Bay $\left(33^{\circ} 51^{\prime} 9^{\prime \prime} \mathrm{S}, 151^{\circ} 16^{\prime} 0^{\prime \prime} \mathrm{E}\right)$ when there were insufficient number of these herbivores at Bare Island. The macroalgal and herbivore communities on subtidal rocky reefs at the depths we worked (1-3 m) at these locations are broadly similar. The common macroalgae at these locations are D. pulchra (except for Shark Bay), the brown algae Ecklonia radiata, Sargassum vestitum, Sargassum linearifolium, Zonaria diesingiana, and Dilophus marginatus, and coralline turfing red algae Corallina officinalis and Amphiroa anceps. The common herbivores are the sea urchins 


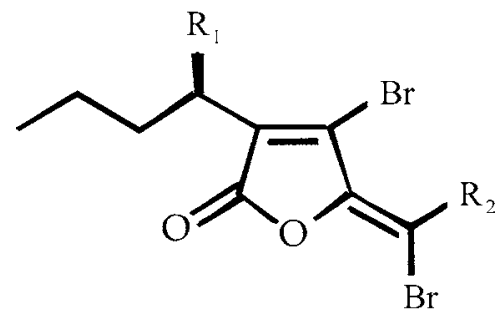

\begin{tabular}{ll}
$\mathrm{R}_{1}$ & $\mathrm{R}_{2}$ \\
\hline
\end{tabular}

(1) $\mathrm{H} \quad \mathrm{Br}$

(2) $\mathrm{H} \quad \mathrm{H}$

(3) OAc H

(4) $\mathrm{OH} \mathrm{H}$

Furanone

FIG. 1. Structure of the major secondary metabolites of Delisea pulchra (compounds 1-4).

Heliocidaris erythrogramma, Heliocidaris tuberculata, Centrostephanus rodgersii, and $H$. purpurascens; the large gastropods Turbo torquatus, Turbo undulatus, and Australium tentiforme; and a variety of mesograzers. Mesograzers common in this region are juvenile $H$. purpurascens, a number of gastropods including Aplysia parvula and Phasianotrochus eximius, Nereid polychaetes and amphipods from the families Ampithoidae, Hyalidae, and Aoridae (Rogers et al. 1998, Poore et al. 2000, Wright et al. 2000b). For further description of these sites see Fletcher (1987), Poore and Steinberg (1999), and Wright and Steinberg (2001).

Delisea pulchra is a common shallow subtidal foliose red alga occurring throughout southern Australia, the Antarctic Peninsula, and various Subantarctic Islands (Ricker 1987, Bonin and Hawkes 1988). Although it is described in the literature as having a triphasic life history (Bonin and Hawkes 1988, Womersley 1996), populations of D. pulchra around Sydney are maintained through asexual reproduction of tetrasporophytes. Random amplified polymorphic DNA (RAPDs) indicated the presence of clones in populations of D. pulchra (Wright et al. 2000a), and an 18month study at Bare Island showed that all reproductive plants over that time were tetrasporophytes (Wright and Steinberg 2001). Furthermore, D. pulchra at Bare Island recycle tetrasporophytes from tetraspores (J. T. Wright, unpublished data), and this appears to be widespread as haploid plants were found in only one out of 15 populations over a $650-\mathrm{km}$ range (Wright et al. $2000 b)$.

Delisea pulchra produces a range of nonpolar halogenated furanones of which four are consistently present in plants and make up $\sim 95 \%$ of total secondary metabolites (Fig. 1; de Nys et al. 1992, 1993). Furanones are contained within specialized gland cells both within and at the surface of the alga (Dworjanyn et al. 1999) and they deter settlement of both eukaryotic and prokaryotic epiphytes (de Nys et al. 1995, Maximilien et al. 1998). Furanones further affect a range of bacterial phenotypes via interference with specific signalbased bacterial regulatory systems (Manefield et al. 1999, Hentzer et al. 2002). D. pulchra is a low preference food for the sea urchin Tripneustes gratilla, the gastropod T. undulatus (Steinberg and Van Altena
1992), and the sea hare A. parvula (Rogers et al. 1995, 2000) and furanones deter feeding by $H$. purpurascens (Williamson et al. 2004). There is considerable variation in the concentrations of furanones in D. pulchra both within plants (de Nys et al. 1996, Dworjanyn et al. 1999, Rogers et al. 2000) and among plants on geographic (between locations) and small (within locations) spatial scales, between different times of the year, and between different life-history stages (Wright et al. 2000b).

\section{Small-scale variation in furanones and herbivores}

Patterns of variation in furanones and herbivore abundance were examined in October 1997 at Cape Banks and Bare Island using the plants and sites described previously to examine genetic structure in $D$. pulchra (see Wright et al. 2000a for a full description of sites and sampling design). Briefly, four $3 \times 3 \mathrm{~m}$ sites were set up at the two locations, which are $\sim 2$ $\mathrm{km}$ apart. Within each of these sites, three $0.5 \times 0.5$ $\mathrm{m}$ quadrats were placed and within each quadrat five D. pulchra plants were randomly collected. At Bare Island, two additional sites were also set up adjacent to the other four sites (Wright et al. 2000a). These two sites had been invaded by high densities of $H$. erythrogramma and had $92.5 \%$ fewer plants than the adjacent uninvaded sites. Plants were collected haphazardly from within these two sites and not from within nested quadrats.

Plants were removed from the substratum, placed into clip seal plastic bags underwater, and taken back to the laboratory. Once there, mesograzers were removed (see next paragraph) and plants weighed. Approximately $1.5 \mathrm{~g}$ of tissue were removed for DNA extraction (Wright et al. 2000a), 20\% of the remaining plant tissue was taken to measure fecundity (Wright 2000 ), and the remainder was frozen at $-20^{\circ} \mathrm{C}$ until extraction and quantitative analysis of furanones. Furanones were extracted and quantified using gas chromatography-mass spectrometry (GC-MS) following the methods of de Nys et al. (1996) and Wright et al. $(2000 b)$. Spatial variation in the concentration of total furanones was analyzed using a nested ANOVA with the levels location, sites within location, and quadrats within sites. Variation in the concentrations of individual furanones was examined with a nested analysis containing the same three spatial levels (location, site, and quadrat) and the additional factors of compound and plant (blocked factor).

As we were interested in examining the potential for selection, we only counted herbivores known to consume D. pulchra. All macroinvertebrates that co-occur with $D$. pulchra consume it to some extent (Steinberg and Van Altena 1992; J. T. Wright, unpublished gut content analysis). Macroinvertebrates were counted in each quadrat at the same time as the D. pulchra was collected. In the two sites invaded by H. erythrograma, macrograzers were counted within 10 haphazardly 
placed quadrats. Gut content analyses or feeding experiments also revealed that four mesograzers: $H$. purpurascens, A. parvula (Rogers et al. 1995, 2000), $P$. eximius, and the nereid polychaete Platynereis dumerilii consumed D. pulchra. The abundance of these four mesograzers on $D$. pulchra was counted by shaking each plant vigorously in freshwater for 20-30 s, which removed all individuals of these species (J. T. Wright, unpublished data). Variation in the abundance of total macrograzers (all species pooled, data $\log x+1$ transformed) was examined between locations and among sites within locations. Variation in the abundance of total mesograzers (all four species pooled, data $\log x$ +1 transformed) was examined between locations, among sites within locations, and among quadrats within sites. The two sites invaded by $H$. erythrograma were not included in any of these hierarchical analyses as D. pulchra and herbivores were not sampled from within nested quadrats in those sites.

\section{Heritability of furanones and gland cells}

The heritability of furanone concentrations and gland cell densities in D. pulchra was examined on plants grown from tetraspores released by 20 tetrasporophytes from Bare Island. As D. pulchra recycles diploid tetrasporophytes from ameiotic tetraspores, the offspring derived from each parent represent clones. Fertile plants were collected and $\sim 5 \mathrm{~g}$ of tissue with tetrasporangia was removed. This tissue was soaked in $1 \%$ betadine solution (1:10 dilution of provadine-iodine solution, Foulding Pharmaceuticals, Salisbury, South Australia) for $3 \mathrm{~min}$, rinsed three times in clean sea water, and then put into a $2-\mathrm{L}$ beaker containing filtered sea water and ceramic settlement tiles $(4 \times 4 \mathrm{~cm})$. Plant tissue was left in these beakers with aeration for $48 \mathrm{~h}$ to release tetraspores onto the unglazed side of the settlement tiles. After $48 \mathrm{~h}$, the tiles were checked for attached tetraspores. Most plants had released sufficient numbers of tetraspores in that time, although four plants were left for an additional $24 \mathrm{~h}$ to release more tetraspores. Individual tiles $(n=4$ per parent) were then placed into 200-mL culture jars containing half strength Provasoli's enriched seawater (PES; Provasoli 1968), $0.01 \mathrm{mg} / \mathrm{mL}$ of Penicillin $\mathrm{G}$, and $0.25 \mathrm{mg} / \mathrm{mL}$ germanium dioxide.

The tetraspores were kept at $20^{\circ} \mathrm{C}$ on a $16: 8$, light: dark cycle with light at $\sim 50 \mathrm{mmol} \cdot \mathrm{m}^{-2} \cdot \mathrm{s}^{-1}$. After 10 $\mathrm{d}$, the tiles were transported back to Bare Island and attached to the substratum in a cage (mesh size $10 \mathrm{~mm}$ ). The tiles were caged as a pilot study showed that uncaged tiles containing sporelings were completely grazed by gastropods and sea urchins (J. T. Wright, unpublished data). Six tiles that lacked sporelings but had been kept in the same culture conditions were also attached to examine natural recruitment of $D$. pulchra during the experiment. No D. pulchra recruited naturally onto the tiles during the experiment. After $71 \mathrm{~d}$ two plants $(1.89 \pm 0.24 \mathrm{mg}$ dry mass, mean $\pm 1 \mathrm{SE})$ were collected from each tile (plants were all nonreproductive) to determine the concentrations of furanones and the number of surface gland cells. All plants were frozen at $-20^{\circ} \mathrm{C}$ until required for extraction or microscopy.

One plant from each tile was freeze-dried, weighed to four decimal places, and then extracted exhaustively with dichloromethane. Methods for the preparation of samples for GC-MS were as described in Wright et al. $(2000 b)$ with the following changes: only three extractions were done with volumes of 800 and $500 \mu \mathrm{L}$ (twice) of dichloromethane; the extract was not filtered; 50 or $25 \mu \mathrm{L}$ (for very small samples) of the internal standard was added to the extracts; and samples were pipetted into inserts that were then placed into GC-MS tubes. GC-MS was then performed as described in de Nys et al. (1996) and Wright et al. (2000b).

Gland cell densities were determined on the second plant following the methods of Dworjanyn et al. (1999). Although gland cells occur both internally and on the surface of $D$. pulchra they are more abundant in the top third of the plant compared to the middle and base (Dworjanyn et al. 1999). We examined genetic variation for the number of surface gland cells $5 \mathrm{~mm}$ down from the mounted apical tip on each plant, in the center of the thallus using a $100 \times 100 \mu \mathrm{m}$ grid.

Differences among clones in the total and individual concentrations of secondary metabolites were analyzed with a one-way analysis of covariance (ANCOVA) with plant mass as the covariate. Mass was not included as a covariate in the analysis of the number of surface gland cells as it was not measured. Differences among clones for the number of surface gland cells were determined using one-way ANOVAs. For all of these analyses, a significant clone effect indicates heritable variation for that trait.

The heritability of these traits was determined as broad-sense (or clonal) heritability (Falconer 1989). Broad-sense heritability $\left(h_{\mathrm{C}}^{2}\right)$ estimates the proportion of the phenotypic variance due to genotypic variance and was calculated as

$$
h_{\mathrm{C}}^{2}=\mathrm{s}_{\mathrm{G}}^{2} /\left(\mathrm{s}_{\mathrm{G}}^{2}+\mathrm{s}_{\mathrm{E}}^{2}\right)
$$

where $\mathrm{s}_{\mathrm{G}}^{2}$ and $\mathrm{s}_{\mathrm{E}}^{2}$ are the variance components due to clone and error, respectively, calculated from the ANOVAs (Falconer 1989, Lynch and Walsh 1998). In nonclonal species, broad-sense heritability overestimates actual heritability as, in addition to additive genetic variance, it includes dominance and interaction effects (Falconer 1989). However, for asexual species such as D. pulchra, it provides an evolutionarily relevant measure of heritability (Lynch and Walsh 1998).

\section{Genetic correlations between furanones and gland cells}

Genetic correlations between furanones and gland cells were estimated and represent the correlations due only to genetic factors. Precise estimates of genetic 
correlations are very difficult to obtain (Cheverud 1988, Falconer 1989, Lynch and Walsh 1998). There are three main methods used to estimate genetic correlations between traits: (1) a pairwise comparison of relatives based on a parent-offspring regression, (2) a nested sib analysis partitioning the covariance into genetic vs. environmental effects, and (3) a correlation between traits using family means (Lynch and Walsh 1998). Method three is considered less rigorous than methods one and two, and at best provides an approximation of the genetic correlation. However, even knowledge of the sign of a genetic correlation is revealing (Lynch and Walsh 1998), and thus genetic correlations based on family means are a useful step in understanding genetic correlations among traits. We estimated genetic correlations among furanones and gland cells for the plants from the heritability experiment by performing correlations on the clone means. Given that D. pulchra reproduces asexually, this was the only one of the three methods that could be applied to examine genetic correlations between traits here.

\section{General methods for feeding experiments}

To investigate the response of herbivores to variation in furanones, we examined the feeding rates on different algae and the effects of nonpolar extract and furanones from $D$. pulchra on feeding by six of the most common herbivores in this system: H. erythrogramma, $H$. purpurascens, T. torquatus, T. undulatus, P. eximius, and A. ngana (Rogers et al. 1998, Poore et al. 2000, Wright et al. 2000b). All feeding experiments were done in the School of Biological, Earth, and Environmental Sciences, University of New South Wales 30-kL recirculating seawater system. Experiments for H. erythrogramma, T. torquatus, and T. undulatus were conducted in 7 -L perspex tanks divided in half with a piece of plastic mesh (1-cm mesh size). Experiments for the canopy dwelling $H$. purpurascens were conducted in individual $130 \times 200 \mathrm{~cm}$ plastic cages (mesh size ranges from 0.5 to $1 \mathrm{~cm}^{2}$ ) placed in 20 -L plastic bins. Six of these cages were placed in each bin with a hose providing flowing seawater directly into each cage. The feeding rate of $A$. ngana was examined in 50-mL perspex jars, while the experiments examining the effects of nonpolar extract and pure compound 3 on this species were done in 20 -L plastic bins divided into 20 rectangular compartments $(8 \mathrm{~cm}$ long, $8 \mathrm{~cm}$ wide, $11 \mathrm{~cm}$ high) separated by $300-\mu \mathrm{m}$ mesh supplied with flowing sea water (see Poore and Steinberg 1999). Experiments for $P$. eximius were done in the $20-\mathrm{L}$ plastic bins divided into 20 compartments as described for A. ngana.

Heliocidaris erythrogramma, H. purpurascens, T. torquatus, and T. undulatus were collected, placed into the experimental tanks, and allowed to feed on a mixture of fresh algae for 2-3 d, after which the experiments were set up. A. ngana and P. eximius were collected and held in cultures in 7-L perspex tanks on a mixture of fresh algae for 1-2 wk until the start of the experiments. Animals were not starved prior to any of the feeding experiments.

\section{Feeding rates of herbivores}

The feeding rates of $H$. erythrogramma, $H$. purpurascens, $T$. torquatus, A. ngana, and $P$. eximius on $D$. pulchra were contrasted to four other algal species $(C$. officianalis, E. radiata, $S$. vestitum, and $Z$. diesingiana) in no-choice feeding assays. The feeding rate of $T$. undulatus on D. pulchra, E. radiata, S. vestitum, and $Z$. diesingiana has been described previously and indicates that D. pulchra is rarely consumed (Steinberg and Van Altena 1992). In our experiments, pieces of algae visually free of epiphytes were cut from freshly collected plants, blotted to a constant wet mass, and weighed. H. erythrogramma, $H$. purpurascens, and $T$. torquatus were presented with $\sim 5$-g pieces, A. ngana with $\sim 25$-mg pieces, and $P$. eximius with $\sim 1$-g pieces of a given alga. In each experiment there were between 8 and 12 replicates of each algal species with herbivores (one animal per tank) and the same number of replicates without herbivores to control for autogenic changes. Herbivore plus and herbivore minus treatments were randomly assigned to a given tank. Experiments ran for $48 \mathrm{~h}$ after which each piece of alga was blotted to a constant wet mass, reweighed, and the differences in feeding rates analyzed with a two-way ANOVA (algal species $\times$ herbivore presence/absence). All replicates were included in the analyses except for several A. ngana individuals that died during the experiment. Tukey's post hoc test within the herbivore treatment was then used to examine for differences among the means of algal species after a correction for autogenic change, using the error mean square from the two-way ANOVA in the Tukey's post hoc tests (Peterson and Renaud 1989).

\section{Effect of nonpolar extract on feeding}

Because D. pulchra was rarely consumed by herbivores here (see Results) and handling of plants for the duration of a feeding experiment causes an unpredictable induced response in furanone concentrations (R. de Nys, O. Ison, A. G. B. Poore, J. T. Wright, and P. D. Steinberg, unpublished manuscript), we were unable to compare consumption of $D$. pulchra tissue with different furanone levels. Therefore, we proceeded to directly test the effects of variation in concentrations of nonpolar extract and compound 3 on feeding.

The effect of nonpolar crude extract from $D$. pulchra on feeding by all six herbivores was examined at three concentrations. Initially we tested the nonpolar extract at an average "natural concentration." This was determined by taking a bulk collection of $\sim 175-200 \mathrm{D}$. pulchra plants from Bare Island (695.6 g dry mass), extracting it sequentially with dichloromethane and then methanol (three times each), and then pooling these extracts. This extract was reduced in vacuo and 
the resultant extract partitioned between dichloromethane and water. The dichloromethane fraction was subsequently reduced in vacuo to yield $41.54 \mathrm{~g}$ dry mass of nonpolar extract that represented a mean concentration of $5.97 \%$ of nonpolar extract. As we wanted to examine the effects of variable concentrations of nonpolar extract on feeding by herbivores, the extract was tested at $5.97 \%$, one-third of this concentration $(1.98 \%)$, and one-sixth of this concentration $(0.99 \%)$. The concentrations of the four main furanones in this bulk nonpolar extract were determined with GC-MS as described previously. These concentrations (per dry mass of plant) were: compound $1(2.93 \mathrm{mg} / \mathrm{g})$, compound $2(4.15 \mathrm{mg} / \mathrm{g})$, compound $3(9.02 \mathrm{mg} / \mathrm{g})$, and compound $4(5.17 \mathrm{mg} / \mathrm{g})$. Therefore concentrations (per dry mass of plant) of total furanones (compounds 14) in the nonpolar extract used in these experiments were $21.26 \mathrm{mg} / \mathrm{g}$ (for $5.97 \%$ ), $7.087 \mathrm{mg} / \mathrm{g}$ (for $1.98 \%$ ), and $3.544 \mathrm{mg} / \mathrm{g}$ (for $0.99 \%$ ).

Experiments to test the deterrent effects of nonpolar extract on feeding by $H$. erythrogramma, T. torquatus, T. undulates, and A. ngana were done using an artificial diet made up of agar and freeze-dried Ulva sp. ground to a powder. $H$. purpurascens and $P$. eximius would not consume any artificial diet and experiments for these two species were done by coating extract onto palatable algae: E. radiata (for $H$. purpurascens) and Ulva sp. for ( $P$. eximius).

To make the artificial diet, freeze-dried Ulva was coated with nonpolar extract at the appropriate concentration (milligrams per gram dry mass) by dissolving the extract in diethyl ether, mixing in the Ulva, and allowing the diethylether to evaporate. For the control food, freeze-dried Ulva was coated with diethylether only. Agar $(4 \% \mathrm{~m} / \mathrm{v})$ was boiled in a microwave and allowed to cool to $\sim 50^{\circ} \mathrm{C}$ before the precoated Ulva was mixed into the agar. The dry:wet mass ratio of the artificial diet (1:8) approximated that of D. pulchra (mean dry:wet mass ratio $1: 7.5, N=48$ plants). For H. erythrogramma, T. torquatus, and T. undulatus disks were made by pouring the mix into $7.5-\mathrm{mL}$ petri dishes with a numbered washer added to identify the different treatments and to ensure the disk sank. For A. ngana the agar mix was poured between two sheets of perspex and flattened to $\sim 1 \mathrm{~mm}$ thick (see Hay et al. 1994). Pieces $\sim 25 \mathrm{mg}$ (wet mass) were cut from this sheet and a small piece of fishing line was pushed through each piece to identify the different treatments.

For $H$. purpurascens, $\sim 2.5$-g (wet mass) pieces of E. radiata were coated on both sides at the appropriate concentration by pipetting the required amount of nonpolar extract dissolved in diethylether. For $P$. eximius 200-mg (wet mass) pieces of Ulva were coated on both sides at the appropriate concentration with the nonpolar extract dissolved in diethylether. For both assays, control pieces of algae were coated with diethylether only.

The two types of food, one with nonpolar extract and one without extract, were presented to single animals in choice experiments. A similar number of tanks were set up with no herbivores to control for autogenic changes during each experiment. Experiments were run until most animals had consumed $\sim 50 \%$ of one food (24-48 h) when the entire experiment was stopped, and analyzed by calculating the difference in mass between the food with and without nonpolar extract for each replicate and performing a $t$ test on these differences between the herbivore plus and herbivore minus treatments (Peterson and Renaud 1989). Herbivore replicates where no consumption occurred were removed from the analyses. This number varied among herbivores: most gastropods and A. ngana ate during these experiments but between $13 \%$ and $30 \%$ of $H$. purpurascens and $15 \%$ and $47 \%$ of $H$. erythrograma did not eat during the experiments. Final sample sizes for these experiments ranged from 10 to 15 replicates. Following this, we then examined whether there were differences in the feeding of each herbivore among the three extract concentrations using a one-factor ANOVA. To do this, for each plus-herbivore replicate we calculated consumption of the plus-extract food scaled to the average consumption of the no-extract food for that experiment (after adjustments for autogenic change), log-transformed the data, and then performed the ANOVA among the three concentrations. Significant variation across the three concentrations indicates concentrationdependent feeding by that herbivore in response to nonpolar extract.

\section{Effect of compound 3 on feeding}

Compound 3 is typically the most abundant furanone in D. pulchra (de Nys et al. 1996, Wright et al. 2000b). It was isolated and purified from the dichloromethane extract using vacuum liquid chromatography followed by high performance liquid chromatography (de Nys et al. 1992). The structure of compound 3 was confirmed by comparison of ${ }^{1} \mathrm{H}$ and ${ }^{13} \mathrm{C}$ nuclear magnetic resonance with reference data (de Nys et al. 1992).

We examined how variation in compound 3 affected feeding by $H$. erythrogramma, T. torquatus, T. undulatus, and $A$. ngana by incorporating it into the artificial diet (see Methods: Effects of nonpolar extract on feeding) at 1,3 , and $5 \mathrm{mg} / \mathrm{g}$ dry mass. These concentrations for compound 3 represent relatively low, mean, and high concentrations based on some previously published values (de Nys et al. 1996, Dworjanyn et al. 1999, Rogers et al. 2000, Wright et al. 2000b), although they are low relative to the concentration in the nonpolar extracts used in our experiments. $H$. purpurascens is strongly deterred by compound 3 at $1 \mathrm{mg} / \mathrm{g}$ dry mass (Williamson et al. 2004) and was not tested here. The design and analyses of the experiments with compound 3 were the same as for the experiments with nonpolar extract.

\section{RESUlts}

Small-scale variation in furanones and herbivores

Concentrations of total and individual furanones did not differ between Bare Island and Cape Banks, or 
TABLE 1. Nested ANOVAs for the effect of location, sites within locations, and quadrats within sites on total and individual furanones in Delisea pulchra.

\begin{tabular}{|c|c|c|c|c|}
\hline Source & $\mathrm{df}$ & MS & $F$ & $P$ \\
\hline \multicolumn{5}{|l|}{ Total furanones } \\
\hline Location & 1 & 50.115 & 0.745 & 0.421 \\
\hline Site (location) & 6 & 67.233 & 2.143 & 0.105 \\
\hline Quadrat (site) & 16 & 31.378 & 1.825 & 0.038 \\
\hline Error & 96 & 17.19 & & \\
\hline \multicolumn{5}{|l|}{ Individual furanones } \\
\hline Location & 1 & 0.251 & 0.295 & 0.607 \\
\hline Site (location) & 6 & 0.852 & 2.023 & 0.122 \\
\hline Quadrat (site) & 16 & 0.421 & 6.923 & $<0.005$ \\
\hline Plant (block) & 4 & 0.395 & 6.492 & $<0.005$ \\
\hline Compound & 3 & 33.051 & 68.858 & 0.003 \\
\hline Location $\times$ compound & 3 & 0.480 & 3.919 & 0.026 \\
\hline Site (location) $\times$ compound & 18 & 0.122 & 1.964 & 0.032 \\
\hline Quadrat $($ site $) \times$ compound & 48 & 0.062 & 1.025 & 0.433 \\
\hline Error & 380 & 0.061 & & \\
\hline
\end{tabular}

among sites within those locations (Table 1). Concentrations of total furanones at Bare Island were 12.25 $\pm 0.49 \mathrm{mg} / \mathrm{g}$ dry mass $(N=90)$ and at Cape Banks were $13.35 \pm 0.60 \mathrm{mg} / \mathrm{g}$ dry mass (mean $\pm 1 \mathrm{SE}, N=$ $60)$. However, there was significant variation among quadrats for both total and individual furanones indicating that most of the variation in concentrations of these compounds lies at small spatial scales (Table 1). Compounds 3 and 4 occurred at higher concentrations than compounds 1 and 2. The concentrations (milligrams per gram dry mass) of these four compounds (mean \pm 1 SE for $N=150$ plants across locations) were: $1.55 \pm 0.05$ (compound 1); $1.17 \pm 0.04$ (compound 2$) ; 4.91 \pm 0.16$ (compound 3 ); and $5.06 \pm 0.19$ (compound 4).

Three macrograzers were recorded in quadrats: the sea urchins Heliocidaris erythrogramma and Holopneustes purpurascens, and the gastropod Turbo torquatus. In the two sites where a wave of high densities of $H$. erythrogramma had entered, there were an average of 82.8 and $61.2 \mathrm{H}$. erythrogramma $/ \mathrm{m}^{2}$. H. purpurascens and $T$. torquatus were much less abundant, rarely being more than one animal $/ \mathrm{m}^{2}$. There were significantly fewer macroinvertebrates at Cape Banks compared to Bare Island $\left(F_{1,6}=11.644, P=0.014\right)$ : only one $H$. erythrogramma and two $T$. torquatus were recorded at Cape Banks. There were also significant differences in the abundance of total macroinvertebrates among sites within locations $\left(F_{6,16}=3.062, P\right.$ $=0.034)$. The most abundant mesograzer was the gastropod Phasianotrochus eximius, which occurred at all sites and reached maximum site densities (mean \pm 1 SE per gram wet mass D. pulchra) of $0.53 \pm 0.12$ at Bare Island and $0.57 \pm 0.14$ at Cape Banks. Overall, there was no difference in total mesograzers per gram D. pulchra (wet mass) between Bare Island and Cape Banks $\left(F_{1,6}=0.114, P=0.747\right)$, there were significant differences in total mesograzers per gram among sites within locations $\left(F_{6,16}=3.963, P=0.013\right)$, but not among quadrats within sites $\left(F_{16,96}=1.567, P=0.093\right)$.

\section{Heritability of furanones and gland cells}

The total concentration of furanones was extremely variable among clones, ranging from $3.8 \pm 0.5$ to 33.9 $\pm 2.5 \mathrm{mg} / \mathrm{g}$ dry mass (mean $\pm 1 \mathrm{SE}$ ). Concentrations of the four individual furanones were also highly variable among clones. For all furanones however, there were significant positive phenotypic correlations between concentration and plant mass ( $r$ ranged from 0.473 to $0.752 ; P<0.001)$. Therefore mass was included as a covariate in the analyses of genetic variation in concentrations of furanones. There was significant genetic variation in the concentrations of compound 3 and total furanones (ANCOVA; Table 2). Compounds 1, 2, and 4 showed no significant genetic variation (although note $P$ values for compounds 1 and 2 ; Table 2). Broad-sense heritabilities for the concentrations of total and individual furanones were relatively low, ranging from 0.058 for compound 4 to 0.321 for compound 3 . The number of surface gland cells also showed significant genetic variation but as was the case for furanones, broad-sense heritability for gland cells was relatively low: 0.240 (Table 2).

Based on the clone means, there were significant positive genetic correlations among all four compounds (Table 3). The number of surface gland cells was not genetically correlated with any of the other traits.

\section{Feeding rates of herbivores}

All herbivores showed differences in feeding rates among algal species (Fig. 2). Qualitatively, D. pulchra was consumed at the lowest rate for all three macrograzers (Fig. 2). Quantitatively, compared to the consumption of $D$. pulchra, $H$. purpurascens consumed significantly more Ecklonia radiata, Sargassum vestitum, and Zonaria diesingiana; H. erythrogramma and T. torquatus consumed significantly more Corallina officianalis and E. radiata; Ampithoe ngana consumed significantly more $Z$. diesingiana and $S$. vestitum; and $P$. eximius consumed significantly more $Z$. diesingiana. 
TABLE 2. Summary of ANCOVAs testing for differences among clones in furanone concentrations and gland cell densities.

\begin{tabular}{|c|c|c|c|c|c|}
\hline \multirow[b]{2}{*}{ Trait } & \multicolumn{2}{|c|}{ Mass (covariate) } & \multicolumn{2}{|c|}{ Clone } & \multirow[b]{2}{*}{$h_{\mathrm{C}}^{2}$} \\
\hline & $F_{1,54}$ & $P$ & $F_{19,54}$ & $P$ & \\
\hline Total furanones & 32.162 & $<0.001$ & 2.224 & 0.011 & 0.234 \\
\hline Compound 1 & 34.954 & $<0.001$ & 1.750 & 0.056 & 0.158 \\
\hline Compound 2 & 29.861 & $<0.001$ & 1.710 & 0.063 & 0.151 \\
\hline Compound 3 & 9.974 & 0.003 & 2.895 & 0.001 & 0.321 \\
\hline Compound 4 & 50.665 & $<0.001$ & 1.246 & 0.258 & 0.058 \\
\hline Gland cells & $\ldots$ & $\ldots$ & $2.266 \dagger$ & 0.009 & 0.240 \\
\hline
\end{tabular}

Notes: Mass was included as a covariate in all analyses for furanones. Broad-sense heritabilities $\left(h_{\mathrm{C}}^{2}\right)$ were calculated using the variance components from the ANCOVA models (see Methods).

$\dagger F_{19,60}$.

Compared to the other four herbivores, $P$. eximius consumed high amounts of $D$. pulchra relative to preferred algae. To further examine the feeding of $P$. eximius on D. pulchra, we tested whether $P$. eximius fed preferentially on the tops vs. bottom of $D$. pulchra in a choice assay. The tops of $D$. pulchra contain higher concentrations of furanones than the bottoms (de Nys et al. 1996, Dworjanyn et al. 1999), and P. eximius consumed significantly more of the tops $(32.1 \pm 3.7$ g) of D. pulchra compared to the bottom (11.8 \pm 3.0 $\mathrm{g} ; t=-4.93, d f=18, P<0.001)$.

\section{Effect of nonpolar extract on feeding}

Nonpolar extract of D. pulchra at $5.97 \%$ dry mass was highly deterrent to feeding by all herbivores except P. eximius (Fig. 3). At $1.98 \%$, nonpolar extract was significantly deterrent to T. torquatus, T. undulatus, and A. ngana and there was no significant reduction in feeding by $H$. purpurascens ( $P=0.085$; Fig. 3$)$. Feeding by $H$. erythrogramma was not deterred by nonpolar extract at this concentration. At $0.99 \%$, nonpolar extract significantly deterred feeding by $H$. purpurascens and $T$. undulatus, but did not deter feeding by $T$. torquatus and A. ngana. There was no significant reduction in feeding by $H$. erythrogramma at this concentration $(P=0.085)$. As $P$. eximius was not deterred at $5.97 \%$, we increased the concentration of nonpolar extract by three and then six times instead of decreasing it. At a concentration of $17.91 \%$, nonpolar extract still did not reduce feeding by $P$. eximius. However, at $35.82 \%$, feeding by $P$. eximius was significantly deterred by nonpolar extract (Fig. 3). ANOVAs performed across the three extract concentrations on scaled consumption of plus-extract food relative to consumption of no-extract food revealed significant dif- ferences in feeding by H. erythrogramma, T. undulatus, $A$. ngana, and $P$. eximius in response to differences in extract concentration. For T. undulatus, A. ngana, and $P$. eximius there was a decrease in feeding with an increase in extract concentration, but for H. erythrogramma there was lower feeding when the extract was at $0.99 \%$ and $5.95 \%$ compared to $1.98 \%$ (Fig. 3). Importantly, with the exception of $H$. erythrogramma and $P$. eximius, an increase in extract concentration from $1.98 \%$ to $5.99 \%$ did not result in significantly greater feeding deterrence.

\section{Effect of compound 3 on feeding}

Compound 3 did not deter feeding by any of the four herbivores at $1 \mathrm{mg} / \mathrm{g}$ dry mass but was deterrent to $H$. erythrogramma, T. torquatus, and T. undulatus at 3 and $5 \mathrm{mg} / \mathrm{g}$ dry mass (Fig. 4). Compound 3 did not deter feeding by the amphipod A. ngana at any of the three concentrations. ANOVAs performed across the three concentrations on scaled consumption of plus-compound 3 food relative to consumption of no-compound 3 food revealed a significant difference in feeding by $T$. torquatus with concentration, but no significant differences for $H$. erythrogramma, $T$. undulatus, or $A$. ngana (Fig. 4). Similar to the response of most herbivores to the nonpolar extract, an increase in the concentration of compound 3 from 3 to $5 \mathrm{mg} / \mathrm{g}$ did not result in significantly greater feeding deterrence for any herbivores tested.

\section{DISCUSSION \\ Heritability of chemical defense}

Although it is well established that quantitative variation in many secondary metabolites from terrestrial

TABLE 3. Genetic correlations $(r)$ among furanone concentrations and gland cell densities based on the clone means $(n=$ 20 clones)

\begin{tabular}{|c|c|c|c|c|c|}
\hline & Compound 1 & Compound 2 & Compound 3 & Compound 4 & Gland cells \\
\hline Compound 1 & & $0.970 * *$ & $0.937 * *$ & $0.837 * *$ & 0.143 \\
\hline Compound 2 & & & $0.904 * *$ & $0.897 * *$ & 0.169 \\
\hline Compound 3 & & & & $0.680 *$ & 0.142 \\
\hline Compound 4 & & & & & 0.143 \\
\hline
\end{tabular}

\footnotetext{
$* P<0.05 ; * * P<0.001$
} 

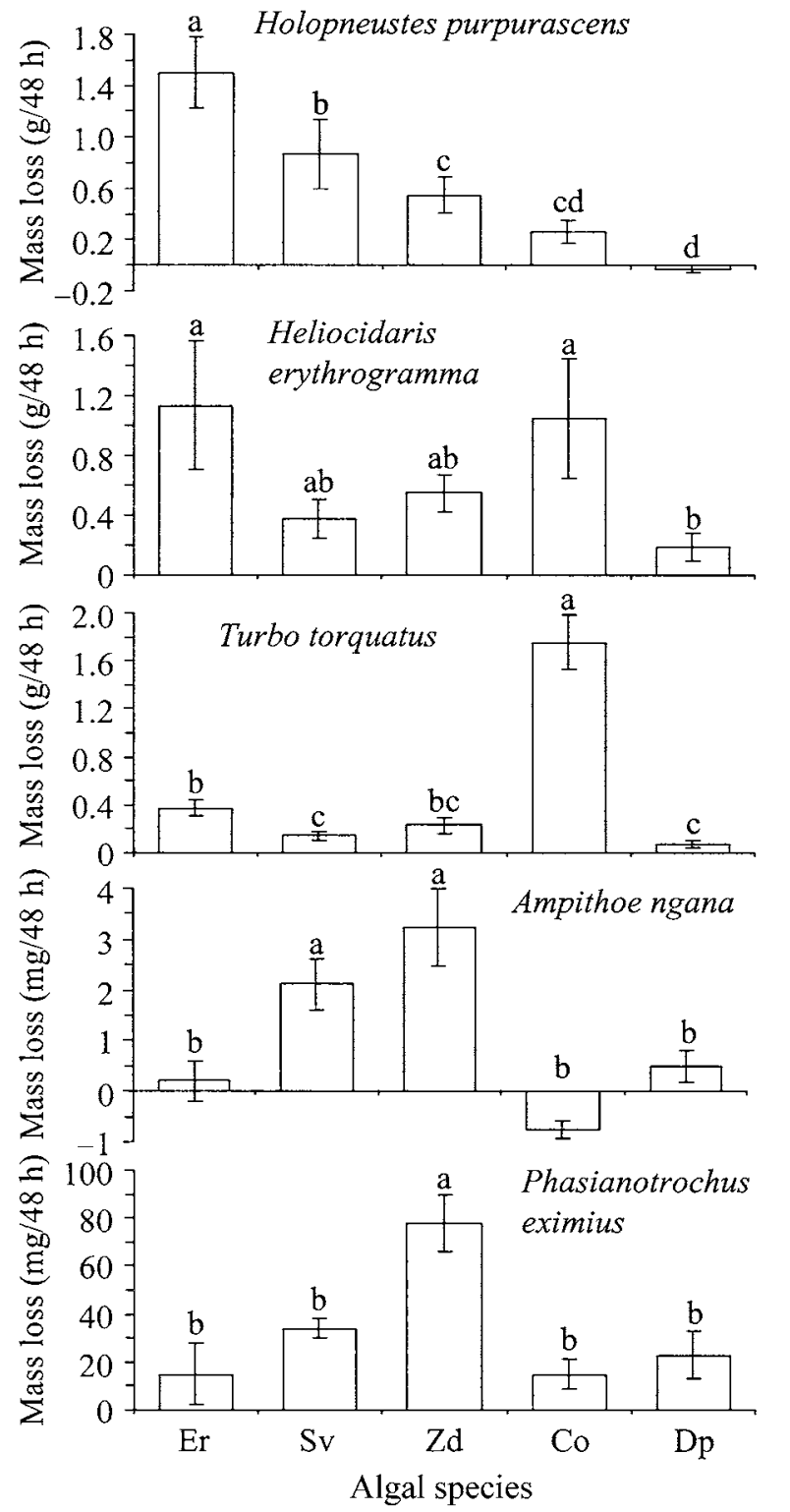

FIG. 2. Feeding rates of herbivores on five algae. The data show the mean $( \pm 1 \mathrm{SE})$ of wet mass loss $(n=10$ for Holopneustes purpurascens, Turbo torquatus, and Phasianotrochus eximius; $n=8$ for Heliocidaris erythrogramma; $n=7$ 11 for Ampithoe ngana). Mass loss has been adjusted for autogenic changes in algae in treatments without herbivores. Bars labeled with the same letter do not differ significantly $(P<0.05)$ in Tukey's post hoc analyses. Key to algal species abbreviations: Er, Ecklonia radiata; Sv, Sargassum vestitum; $\mathrm{Zd}$, Zonaria diesingiana; Co, Corallina officianalis; Dp, Delisea pulchra.

plants is heritable (Berenbaum and Zangerl 1992, Hamilton et al. 2001), there have been no previous examinations of the genetic basis to quantitative variation in the secondary metabolites of marine algae. In $\mathrm{De}$ lisea pulchra, variation in total furanone concentration had a significant genetic basis but heritability of the four individual furanones varied. Similar differences in the heritability of secondary metabolites occur within species of terrestrial plants (Zangerl et al. 1989, Zangerl and Berenbaum 1990). Interestingly, in D. pulchra the heritabilities of both total and individual furanones were generally lower than those described for secondary metabolites from terrestrial plants (Berenbaum and Zangerl 1992, Hamilton et al. 2001) suggesting strong environmental effects on their variation. A range of environmental factors influence quantitative variation in algal secondary metabolites (Yates and Peckol 1993, Arnold et al. 1995, Cronin and Hay $1996 a, b$, Puglisi and Paul 1997) but their relative effects on furanones are unclear. As furanones are restricted to gland cells in D. pulchra (Dworjanyn et al. 1999), gland cell density may have important implications and possibly place constraints on furanone concentrations (e.g., Zangerl et al. 1989). However, despite the significant genetic basis to surface gland cell density, the absence of significant correlations between surface gland cell abundance and furanones suggests no constraints on furanone concentrations as a function of gland cell density, although the density of internal gland cells and the size of both surface and internal gland cells were not measured here.

Maternal effects on offspring (Lynch and Walsh 1998) may have inflated our estimates of broad-sense heritability for furanones and gland cells. The maternal effect of tetrasporophytes on tetraspores is unknown. However, red algal spores are small (D. pulchra tetraspores are $\sim 20 \mu \mathrm{m}$ diameter), contain very limited amounts of nutritional material (Santelices 1990), and mechanisms for maternal effects in red algae are unknown. Hence, we have assumed that maternal effects on variation in furanone concentration and gland cell density were small.

\section{Feeding by herbivores and the potential for them to impose selection}

The finding of genetic variation for concentrations of furanones in D. pulchra indicates that there is the potential for furanones to evolve in response to selection by natural enemies, although the relatively low heritability for furanones suggests that the response would be slow. In terrestrial plants, insect herbivores can select for both increased concentrations of secondary metabolites (Mauricio and Rausher 1997) or to maintain intermediate concentrations (Shonle and Bergelson 2000). In contrast to terrestrial plants where specialized feeding by insect herbivores is common (Bernays and Chapman 1994) and a specific defensive response to individual herbivore species may be expected, marine algae are predicted to evolve defenses that are deterrent to a diverse range of generalist herbivores because specialist marine herbivores are rare (Hay and Steinberg 1992). The low consumption of $D$. pulchra by most herbivores and the strong deterrence by naturally occurring levels of nonpolar extract (Table 4) indicate the chemical defenses of D. pulchra fit that 


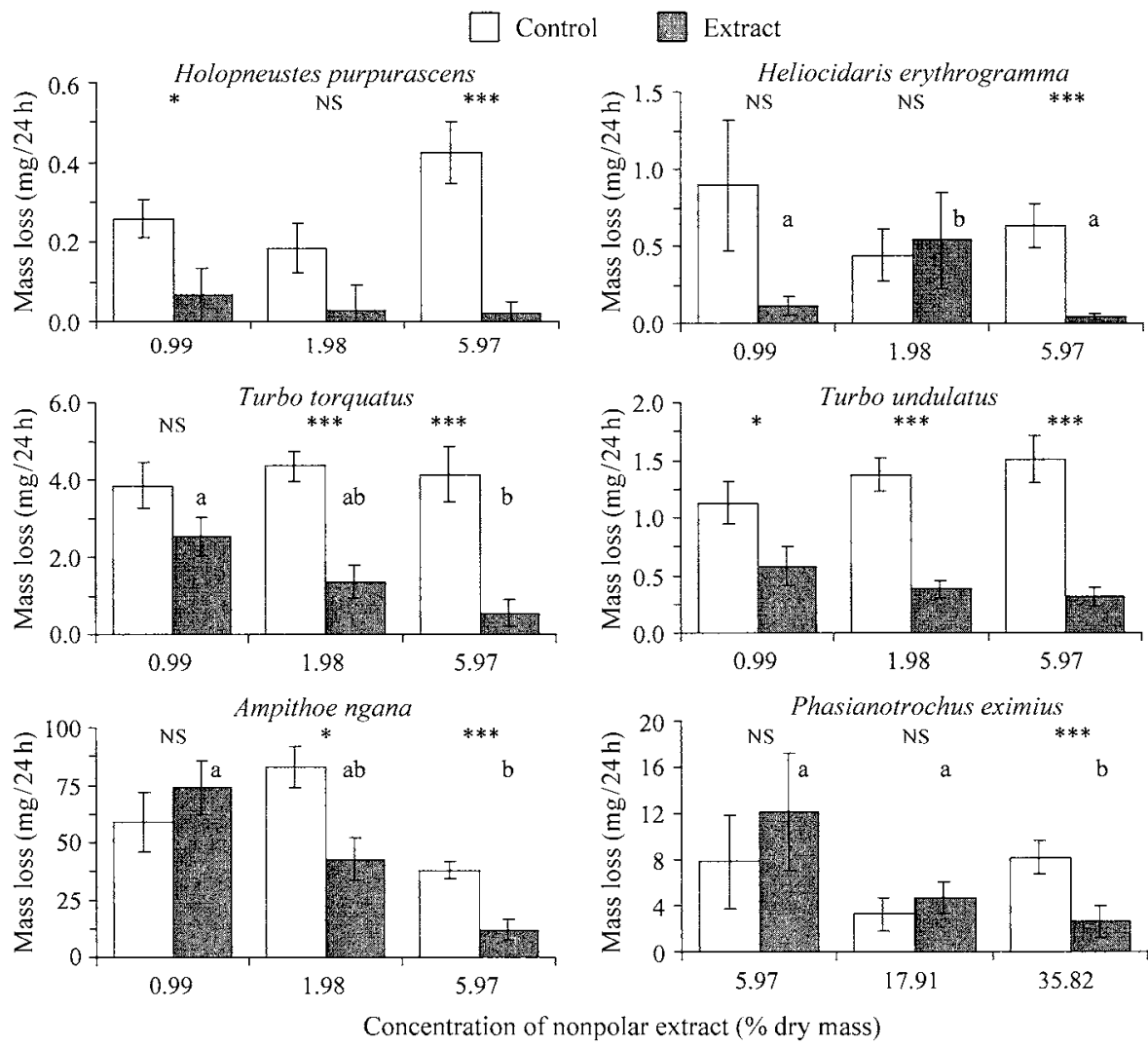

FIG. 3. The effect of three concentrations of nonpolar extract from Delisea pulchra on feeding by six herbivores. Bars show the mean $( \pm 1 \mathrm{SE})$ amount of food consumed (wet mass) per replicate over $24 \mathrm{~h}$ after adjustment for autogenic change ( $n$ ranged from 10 to 15 ). Asterisks indicate $P$ values from $t$ tests following Peterson and Renaud (1989): *P<0.05;**P $<0.01 ; * * * P<0.001$; NS, not significant. The results of ANOVAs testing for differences in deterrence among the three concentrations were: $H$. purpurascens $\left(F_{2,33}=1.129, P=0.336\right) ; H$. erythrogramma $\left(F_{2,31}=5.338, P=0.010\right) ;$ T. torquatus $\left(F_{235}=5.052, P=0.012\right) ; T$. undulatus $\left(F_{2,40}=0.398, P=0.674\right) ;$ A. ngana $\left(F_{2,27}=10.184, P=0.001\right) ; P$. eximius $\left(F_{238}\right.$ $=4.282, P=0.021)$. For the herbivores for which the three extract concentrations differed in deterrence, shared letters above the plus extract bars indicate those concentrations that did not differ $(P>0.05$, Tukey's test $)$.

prediction. The herbivores associated with D. pulchra appear to fall into two broad groups: species that consume very little $D$. pulchra and are deterred by naturally occurring concentrations of furanones except when they occur at very low levels (most herbivores), and species that appear adapted to consuming $D$. pulchra and are not deterred by any naturally occurring concentration of furanones (e.g., Phasianotrochus eximius: Table 4). The finding that macrograzers were not deterred by compound 3 at $1 \mathrm{mg} / \mathrm{g}$ dry mass but were deterred at $3 \mathrm{mg} / \mathrm{g}$ dry mass indicates the potential for selection by those herbivores for concentrations of compound $3>1 \mathrm{mg} / \mathrm{g}$ dry mass. Compound 3 occurred at concentrations $>3 \mathrm{mg} / \mathrm{g}$ dry mass in $79 \%$ of plants at Bare Island and $88 \%$ of plants at Cape Banks. Thus, most plants in those populations were chemically defended against those herbivores and overall, deterrence occurred at the low end of the range of concentrations. Studies examining the effects of quantitative variation in other algal secondary metabolites on feeding by herbivores are uncommon, but they suggest deterrence of- ten occurs at the high end of the concentration range at which those compounds occur (Cronin and Hay $1996 b, c)$. Lower concentrations of furanones in D. pulchra have been recorded in plants at other places and times (de Nys et al. 1996, Wright et al. 2000b), and they may represent crucial windows for herbivores to act as selective agents on furanone concentrations.

Of the herbivores tested in this system, the two mesograzers were less deterred by nonpolar extract and furanones than macrograzers. $P$. eximius also preferentially consumed furanone rich tops of plants to the bottoms, as does the sea hare Aplysia parvula (Rogers 2000). Mesograzers are often less deterred by concentrations of algal secondary metabolites that are deterrent to macrograzers and herbivorous fish (Hay et al. 1987, Duffy and Hay 1994). By feeding on chemically defended plants, some mesograzers experience lower predation by fish than they would on more palatable species (Hay et al. 1989, 1990, Duffy and Hay 1994). The mechanism by which $P$. eximius is able to tolerate feeding on D. pulchra is unclear. It is not a specialist 
Control Compound 3
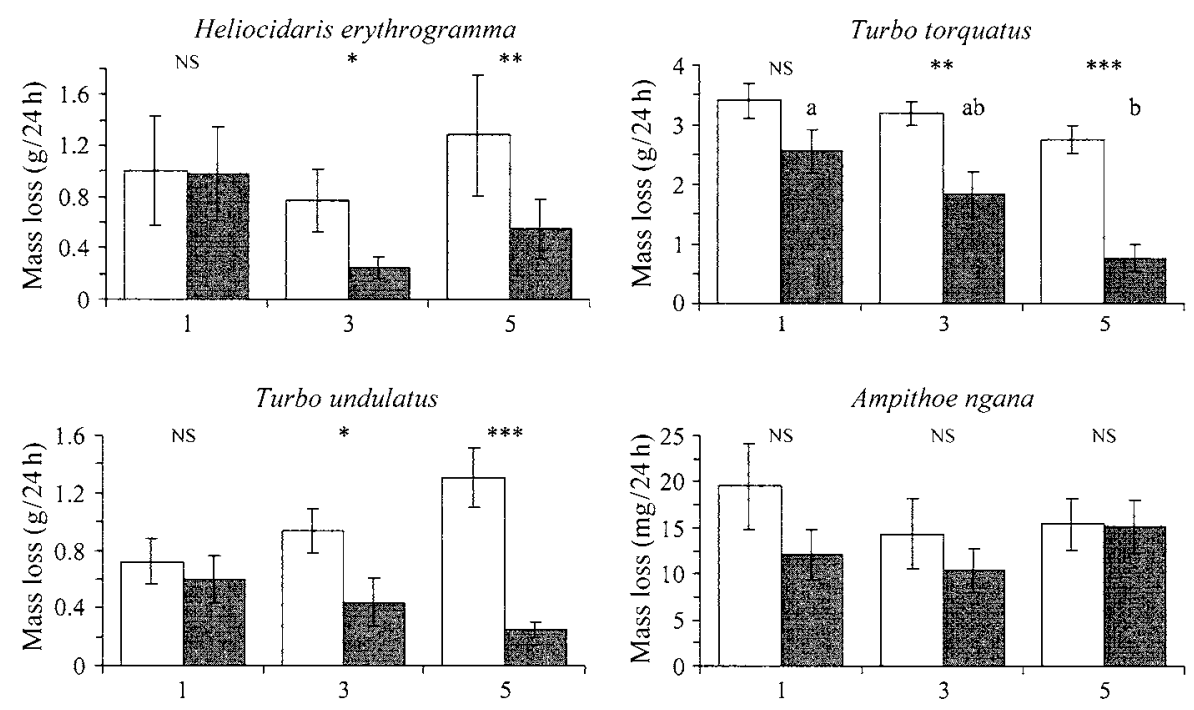

Concentration of furanones (mg/g dry mass)

FIG. 4. The effect of quantitative variation in compound 3 on feeding by four herbivores. Bars show the mean $( \pm 1$ SE) amount of food consumed (wet mass) per replicate over $24 \mathrm{~h}$ after adjustment for autogenic change ( $n$ ranged from 6 to 13 ). Asterisks indicate $P$ values from $t$ tests following Peterson and Renaud (1989): $* P<0.05 ; * * P<0.01 ; * * * P<0.001$; NS, not significant. The results of ANOVAs testing for differences in deterrence among the three concentrations were as follows: H. erythrogramma $\left(F_{2,25}=1.607, P=0.220\right) ;$. torquatus $\left(F_{2,32}=4.311, P=0.022\right) ;$. undulatus $\left(F_{2,31}=0.309, P=\right.$ $0.069)$; A. ngana $\left(F_{2,30}=1.196, P=0.316\right)$. For $T$. torquatus, shared letters above the plus compound-3 bars indicate those concentrations that did not differ $(P>0.05$, Tukey's test).

feeder and does not sequester or store these compounds (R. de Nys, unpublished data). The furanone-containing gland cells, which occur at higher densities in the tops of the alga, are not limited to the apical meristems (Dworjanwn et al. 1999), and P. eximius does not selectively graze around small regions of tissue with low concentrations of secondary metabolites as has been documented for herbivorous amphipods on Zonaria augustata (Poore 1994).
The potential selective impact of any herbivore species is likely to be important if its impact is large relative to that of all other species. Although mesograzers can have important effects on temperate macroalgae (Duffy and Hay 2000), the sea urchin H. erythrogram$m a$ is very abundant, consumes more mass of $D$. pulchra per capita than other herbivores, and has a major impact on D. pulchra recruitment and survivorship when it reaches high densities (Wright and Steinberg

TABLE 4. Summary table describing the feeding by herbivores on D. pulchra vs. other macroalgae, and the effects of three concentrations of nonpolar extract and three concentrations of compound 3.

\begin{tabular}{|c|c|c|c|c|c|c|c|}
\hline \multirow[b]{2}{*}{ Herbivore } & \multirow{2}{*}{$\begin{array}{l}\text { D. pulchra } \\
\text { vs. } \\
\text { other algae }\end{array}$} & \multicolumn{3}{|c|}{$\begin{array}{l}\text { Nonpolar extract } \\
\text { (\% dry mass) }\end{array}$} & \multicolumn{3}{|c|}{$\begin{array}{c}\text { Compound } 3 \\
\text { (mg/g dry mass) }\end{array}$} \\
\hline & & 0.99 & 1.98 & 5.97 & 1 & 3 & 5 \\
\hline \multicolumn{8}{|l|}{ Sea urchins } \\
\hline Heliocidaris erythrogramma & low & (D) & $\mathrm{N}$ & $\mathrm{D}$ & $\mathrm{N}$ & $\mathrm{D}$ & $\mathrm{D}$ \\
\hline Holopneustes purpurascens & very low & $\mathrm{D}$ & (D) & $\mathrm{D}$ & $\mathrm{D}$ & .. & .. \\
\hline \multicolumn{8}{|l|}{ Gastropods } \\
\hline Turbo torquatus & low & $\mathrm{N}$ & $\mathrm{D}$ & $\mathrm{D}$ & $\mathrm{N}$ & $\mathrm{D}$ & $\mathrm{D}$ \\
\hline Turbo undulatus & low $\dagger$ & $\mathrm{D}$ & $\mathrm{D}$ & $\mathrm{D}$ & $\mathrm{N}$ & $\mathrm{D}$ & $\mathrm{D}$ \\
\hline \multicolumn{8}{|l|}{ Mesograzers } \\
\hline Phasianotrochus eximius & mid & & $\cdots$ & $\mathrm{N}$ & & & $\ldots$ \\
\hline Ampithoe ngana & low/mid & $\mathrm{N}$ & D & $\mathrm{D}$ & (D) & $\mathrm{N}$ & $\mathrm{N}$ \\
\hline
\end{tabular}

Notes: Key to symbols: D, deterrent at $P<0.05$; (D), deterrent at $P<0.1 ; \mathrm{N}$, not deterrent. Ellipses (...) indicate "not tested."

Sources: Steinberg and Van Altena (1992), Williamson et al. (2004), and present study.

$\dagger$ Choice and no-choice experiments done. 
2001). Despite this abundance and impact, H. erythrogramma does not appear to select $D$. pulchra individuals on either a chemical or genetic basis. At Bare Island, D. pulchra from the sites where $>90 \%$ of plants had been removed by grazing by high densities of $H$. erythrogramma did not differ in concentrations of total furanones $\left(F_{1,58}=0.961, P>0.5\right)$ or random amplified polymorphic DNAs (RAPD) banding patterns (Wright et al. 2000a) compared to adjacent ungrazed sites. All D. pulchra were eventually removed at these high urchin densities, and the longer survivorship of some plants may simply be determined by the distribution of $H$. erythrogramma in space.

There are three constraints regarding our conclusions that herbivores have the potential to act as selective agents for concentrations of furanones above very low levels. First, the presentation of furanones in the artificial diets may not accurately reflect how they are presented to herbivores in the plants. This issue is important because we were unable to provide any data on the feeding rate by herbivores on $D$. pulchra tissue that differed in concentrations of furanones, and we used different artificial diets for different herbivores. However, in general both the qualitative and quantitative responses of all herbivores to nonpolar extract and compound 3 reflected their feeding rates on $D$. pulchra tissue (Table 4). Thus we are confident our experiments provide meaningful data. Second, feeding in laboratory experiments may not reflect field consumption. Because we examined the feeding response of individual species, controlling for other herbivores and ensuring autogenic controls lacked herbivores were most easily done in the laboratory. Experiments to examine feeding deterrence of marine algal secondary metabolites are routinely performed in laboratory experiments (see references in Hay and Steinberg 1992, Paul et al. 2001). Third, we have not examined feeding by herbivorous fishes. Although several herbivorous fish occur in this region, their diet and habitat preferences suggest that with the exception of Girella tricuspudata, most are unlikely to consume D. pulchra (Andrew and Jones 1990, Clements and Choat 1997, Curley et al. 2002) and none have ever been observed grazing it.

There are also two important evolutionary constraints. First, because furanones also deter the settlement of epiphytes (de Nys et al. 1995) and inhibit colonization, movement, and biofilm development by bacteria (Maximilien et al. 1998, Hentzer et al. 2002), there are many natural enemies that may impose selective pressure on different furanones and/or furanone concentrations. However, relative to the combined (diffuse) selective pressures by natural enemies, any selective pressure imposed by individual species will be weak. Consequently, a specific pairwise coevolutionary response between furanones and single enemies is unlikely, becuase selection should favor generalized defenses (Fox 1981), which appears to be the case for D. pulchra. In addition, because all four furanones are genetically correlated, selection on individual furanones will cause a correlated change in the others. Genetic correlations arise because of pleiotropy, which is likely if structurally similar compounds such as the four furanones are produced via the same biochemical pathways, or through linkage disequilibrium (Falconer 1989, Lynch and Walsh 1998).

Finally, any cost of furanones to D. pulchra may represent a further constraint on their evolution. Most models for the evolution of resistance in plants assume that as well as having a benefit, resistance traits also impose a cost by directing resources away from growth and reproduction (Strauss et al. 2002) and stress tolerance (Cronin 2001). Furanones clearly provide a benefit to $D$. pulchra by deterring natural enemies but they usually occur at higher concentrations than needed to achieve this, suggesting they impose little cost. A companion study to this paper indicates the cost of furanones to D. pulchra is complex and depends on the life-cycle stage (sporelings, juveniles, and adults) being examined (S. A. Dworjanyn, J. T. Wright, N. Paul, R. de Nys, and P. D. Steinberg, unpublished manuscript).

\section{ACKNOWLEDGMENTS}

We are indebted to Tim Charlton, Katy Crass, Nicole Hill, Odette Ison, Sophia McCloy, Neda Shakibaee, and Rebecca Swanson for assistance with this project. We also thank the Ray Williams Biomedical Mass Spectrometry Facility at U. N. S. W for help with furanone analyses. Comments by Kenneth Raffa and two anonymous reviewers greatly improved an earlier version of this manuscript. The Australian Research Council and the Centre for Marine Biofouling and Bio-Innovation provided financial support. J. T. Wright and A. G. B. Poore were supported by A. P. A. postgraduate research scholarships.

\section{Literature Cited}

Andrew, N. L. 1993. Spatial heterogeneity, sea urchin grazing, and habitat structure on reefs in temperate Australia. Ecology 74:292-302.

Andrew, N. L., and G. P. Jones. 1990. Patch formation by herbivorous fish in a temperate Australian kelp forest. Oecologia 85:57-68.

Arnold, T. M., C. E. Tanner, and W. I. Hatch. 1995. Phenotypic variation in polyphenolic content of the tropical brown alga Lobophora variegata as a function of nitrogen availability. Marine Ecology Progress Series 123:177-183.

Berenbaum, M. R., and A. R. Zangerl. 1992. Genetics of secondary metabolism and herbivore resistance in plants. Pages 415-438 in G. A. Rosenthal and M. R. Berenbaum, editors. Herbivores: their interaction with secondary plant metabolites. Volume 2: Ecological and evolutionary processes. Academic Press, San Diego, California, USA.

Berenbaum, M. R., A. R. Zangerl, and J. K. Nitao. 1986. Constraints on chemical coevolution: wild parsnips and the parsnip webworm. Evolution 40:1215-1228.

Bernays, E. A., and R. F. Chapman. 1994. Host-plant selection by phytophageous insects. Chapman and Hall, New York, New York, USA.

Bonin, D. R., and M. W. Hawkes. 1988. Systematics and life histories of the New Zealand Bonnemaisoneaceae (Bonnemaisonales, Rhodophyta): II. The genus Delisea. New Zealand Journal of Botany 26:619-632. 
Carpenter, R. C. 1986. Partitioning herbivory and its effects on coral reef algal communities. Ecological Monographs 56:345-363.

Cheverud, J. M. 1988. A comparison of genetic and phenotypic correlations. Evolution 42:958-968.

Clements, K. D., and J. H. Choat. 1997. Comparison of herbivory in the closely-related marine fish genera Girella and Kyphosus. Marine Biology 127:579-586.

Cronin, G. 2001. Resource allocation in seaweeds and marine invertebrates: chemical defense patterns in relation to defense theories. Pages 325-353 in J. B. McClintock and B. J. Baker, editors. Marine chemical ecology. CRC Press, Boca Raton, Florida, USA.

Cronin, G., and M. E. Hay. 1996a. Effects of light and nutrient availability on the growth, secondary chemistry, and resistance to herbivory of two brown seaweeds. Oikos 77: 93-106.

Cronin, G., and M. E. Hay. 1996b. Induction of seaweed chemical defenses by amphipod grazing. Ecology 77:22872301.

Cronin, G., and M. E. Hay. 1996c. Susceptibility to marine herbivores depends on recent history of both the plant and animal. Ecology 77:1531-1543.

Curley, B. G., M. J. Kingsford, and B. M. Gillanders. 2002. Spatial and habitat-related patterns of temperate reef fish assemblages: implications for the design of Marine Protected Areas. Marine and Freshwater Research 53:11971210.

Dean, T. A., S. C. Schroeter, and J. D. Dixon. 1984. Effects of grazing by two species of sea urchins (Strongylocentrotus franciscanus and Lytechinus anamesus) on recruitment and survival of two species of kelp (Macrocystis pyrifera and Pterygophera californica). Marine Biology 78:301313.

de Nys, R., J. C. Coll, and B. F. Bowden. 1992. Delisea pulchra (cf. fimbriata) revisited. The structural determination of two new metabolites from the red alga Delisea pulchra. Australian Journal of Chemistry 45:1625-1632.

de Nys, R., J. Coll, and I. Price. 1991. Chemically mediated interactions between the red alga Plocamium hamatum and the octocoral Sinularia cruciata (Alcyonacea). Marine Biology 108:315-320.

de Nys, R., P. D. Steinberg, C. N. Rogers, T. S. Charlton, and M. W. Duncan. 1996. Quantitative variation of secondary metabolites in the sea hare Aplysia parvula and its host plant, Delisea pulchra. Marine Ecology Progress Series 130:135-146.

de Nys, R., P. D. Steinberg, P. Willemson, S. A. Dworjanyn, C. L. Gabelish, and R. J. King. 1995. Broad spectrum effects of secondary metabolites from the red alga Delisea pulchra in antifouling assays. Biofouling 8:259-271.

de Nys, R., A. D. Wright, G. M. Konig, and O. Sticher. 1993. New halogenated furanones from the marine alga Delisea pulchra (cf. fimbriata). Tetrahedron 49:11213-11220.

Duffy, J. E., and M. E. Hay. 1994. Herbivore resistance to seaweed chemical defense: the roles of herbivore mobility and predation risk. Ecology 75:1304-1319.

Duffy, J. E., and M. E. Hay. 2000. Strong impacts of grazing amphipods on the organization of a benthic community. Ecological Monographs 70:237-263.

Dworjanyn, S. A., R. de Nys, and P. D. Steinberg. 1999. Localisation and surface quantification of secondary metabolites in the red alga Delisea pulchra. Marine Biology 133:727-736.

Erlich, P. R., and P. H. Raven. 1964. Butterflies and plants: a study in coevolution. Evolution 18:586-608.

Falconer, D. S. 1989. Introduction to quantitative genetics. Third edition. Longman Scientific and Technical, New York, New York, USA.
Fletcher, W. J. 1987. Interactions among subtidal Australian sea urchins, gastropods, and algae: effects of experimental removals. Ecological Monographs 57:89-109.

Fox, L. R. 1981. Defense and dynamics in plant-herbivore systems. American Zoologist 21:853-864.

Fritz, R. S., and P. W. Price. 1988. Genetic variation among plants and insect community structure: willows and sawflies. Ecology 69:845-856.

Fritz, R. S., and E. L. Simms. 1992. Plant resistance to herbivores and pathogens. University of Chicago Press, Chicago, Illinois, USA.

Futuyma, D. J. 1983. Evolutionary interactions among herbivorous insects and plants. Pages 207-231 in D. J. Futuyma and M. Slatkin, editors. Coevolution. Sinauer, Sunderland, Massachusetts, USA.

Hamilton, J. G., A. R. Zangerl, E. H. DeLucia, and M. R. Berenbaum. 2001. The carbon-nutrient balance hypothesis: its rise and fall. Ecology Letters 4:86-95.

Harvell, C. D. 1998. Genetic variation and polymorphism in the inducible spines of a marine bryozoan. Evolution 52: 80-86.

Hawkins, S. J., and R. G. Hartnoll. 1983. Grazing of intertidal algae by marine invertebrates. Oceanography and Marine Biology: an Annual Review 21:195-282.

Hay, M. E., J. E. Duffy, V. J. Paul, P. E. Renaud, and W. Fenical. 1990. Specialist herbivores reduce their susceptibility to predation by feeding on the chemically-defended seaweed Avrainvillea longicaulis. Limnology and Oceanography 35:1734-1743.

Hay, M. E., J. E. Duffy, C. A. Pfister, and W. Fenical. 1987. Chemical defense against different marine herbivores: are amphipods insect equivalents? Ecology 68:1567-1580.

Hay, M. E., Q. E. Kappel, and W. Fenical. 1994. Synergisms in plant defenses against herbivores: interactions of chemistry, calcification and plant quality. Ecology 75:17141726.

Hay, M. E., J. R. Pawlik, J. E. Duffy, and W. Fenical. 1989. Seaweed-herbivore-predator interactions: host-plant specialization reduces predation on small herbivores. Oecologia 81:418-427.

Hay, M. E., and P. D. Steinberg. 1992. The chemical ecology of plant-herbivore interactions in marine versus terrestrial communities. Pages 371-413 in G. A. Rosenthal and M. Berenbaum, editors. Herbivores: their interaction with plant secondary metabolites. Volume 2: Ecological and evolutionary processes. Academic Press, San Diego, California, USA.

Hentzer, M., K. Riedel, T. B. Rasmussen, A. Heydorn, J. B. Anderson, M. R. Parsek, S. A. Rice, L. Eberl, S. Molin, N. Hoiby, S. Kjelleberg, and M. Givsov. 2002. Inhibition of quorum sensing in Pseudomonas aeruginosa biofilm bacteria by a halogenated furanone compound. Microbiology 148: $87-202$

Lynch, M., and B. Walsh. 1998. Genetics and analysis of quantitative traits. Sinauer Associates, Sunderland, Massachusetts, USA.

Manefield, M., R. de Nys, N. Kumar, R. Read, M. Giskov, P. D. Steinberg, and S. Kjelleberg. 1999. Evidence that halogenated furanones from Delisea pulchra inhibit homoserine lactone (AHL)-mediated gene expression by displacing the AHL signal from its receptor protein. Microbiology 145:283-291.

Marquis, R. J. 1992. Selective impact of herbivores. Pages 301-324 in R. S. Fritz and E. L. Simms, editors. Plant resistance to herbivores and pathogens. University of Chicago Press, Chicago, Illinois, USA.

Masuda, M., T. Abe, S. Sato, T. Suzuki, and M. Suzuki. 1997. Diversity of halogenated secondary metabolites in the red alga Laurencia nipponica (Rhodomelaceae, Ceramiales). Journal of Phycology 33:196-208. 
Mauricio, R. 1998. Costs of resistance to natural enemies in field populations of the annual plant Arabidopsis thaliana. American Naturalist 151:20-28.

Mauricio, R., and M. D. Rausher. 1997. Experimental manipulation of putative selection agents provides evidence for the role of natural enemies in the evolution of plant defense. Evolution 51:1435-1444.

Maximilien, R., R. de Nys, C. Holmstrom, L. Gram, M. Giskov, K. Crass, S. Kjelleberg, and P. D. Steinberg. 1998. Chemical mediation of bacterial surface colonization by secondary metabolites from the red alga Delisea pulchra. Aquatic Microbial Ecology 15:233-246.

Paul, V. J., E. Cruz-Rivera, and R. W. Thacker. 2001. Chemical mediation of macroalgal-herbivore interactions: ecological and evolutionary perspectives. Pages 227-265 in J. B. McClintock and B. J. Baker, editors. Marine chemical ecology. CRC Press, Boca Raton, Florida, USA.

Peterson, C. H., and P. E. Renaud. 1989. Analysis of feeding preference experiments. Oecologia 80:82-86.

Poore, A. G. B. 1994. Selective herbivory by amphipods inhabiting the brown alga Zonaria angustata. Marine Ecology Progress Series 107:113-122.

Poore, A. G. B., and P. D. Steinberg. 1999. Preference-performance relationships and effects of host plant choice in an herbivorous marine amphipod. Ecological Monographs 69:443-464.

Poore, A. G. B., M. J. Watson, R. de Nys, J. K. Lowry, and P. D. Steinberg. 2000. Patterns of host use among algaand sponge-associated amphipods. Marine Ecology Progress Series 208:183-196.

Provasoli, L. 1968. Media and prospects for cultivation of marine algae. Pages 63-75 in A. Watanabe and A. Hattori, editors. Cultures and collection of algae. Japanese Society of Plant Physiologists, Tokyo, Japan.

Puglisi, M. P., and V. J. Paul. 1997. Intraspecific variation in the red alga Portieria hornemannii: monoterpene concentrations are not influenced by nitrogen or phosphorus enrichment. Marine Biology 128:161-170.

Rausher, M. D. 1996. Genetic analysis of coevolution between plants and their natural enemies. Trends in Genetics 12:212-217.

Ricker, R. W. 1987. Taxonomy and biogeography of Macquarie Island seaweeds. British Museum (Natural History), London, UK.

Rogers, C. N. 2000. The costs and benefits of acquired algal secondary metabolites to Aplysia parvula. Dissertation. University of New South Wales, New South Wales, Australia.

Rogers, C. N., R. de Nys, T. S. Charlton, and P. D. Steinberg. 2000. Dynamics of algal secondary metabolites in two species of sea hare. Journal of Chemical Ecology 26:721-744.

Rogers, C. N., P. D. Steinberg, and R. de Nys. 1995. Factors associated with oligophagy in two species of sea hares (Mollusca: Anapsidea). Journal of Experimental Marine Biology and Ecology 192:47-73.

Rogers, C. N., J. E. Williamson, D. G. Carson, and P. D. Steinberg. 1998. Diel vertical movement by mesograzers on seaweeds. Marine Ecology Progress Series 166:301306.

Rosenthal, G. A., and M. R. Berenbaum. 1992. Herbivores: their interactions with plant secondary metabolites. Volume 2. Ecological and evolutionary processes. Academic Press, San Diego, California, USA.

Santelices, B. 1990. Patterns of reproduction, dispersal and recruitment in seaweeds. Oceanography and Marine Biology: an Annual Review 28:177-276.

Schmitt, T. M., M. E. Hay, and N. Lindquist. 1995. Constraints on chemically mediated coevolution: multiple func- tions for seaweed secondary metabolites. Ecology 76:107123.

Shonle, I., and J. Bergelson. 2000. Evolutionary ecology of the tropane alkaloids of Datura stramonium L. (Solanaceae). Evolution 54:778-788.

Simms, E. L., and M. D. Rausher. 1989. The evolution of resistance to herbivory in Ipomoea purpurea. II. Natural selection by insects and costs of resistance. Evolution 43: $573-585$.

Simms, E. L., and M. D. Rausher. 1992. Uses of quantitative genetics for studying the evolution of plant resistance. Pages 42-68 in R. S. Fritz and E. L. Simms, editors. Plant resistance to herbivores and pathogens. University of Chicago Press, Chicago, Illinois, USA.

Steinberg, P. D. 1988. Effects of quantitative and qualitative variation in phenolic compounds on feeding in three species of marine invertebrate herbivores. Journal of Experimental Marine Biology and Ecology 120:221-237.

Steinberg, P. D. 1992. Geographical variation in the interaction between marine herbivores and brown algal secondary metabolites. Pages 51-92 in V. J. Paul, editor. Ecological roles for marine secondary metabolites. Cornell University Press, Ithaca, New York, USA.

Steinberg, P. D., and I. Van Altena. 1992. Tolerance of marine invertebrate herbivores to brown algal phlorotannins in temperate Australasia. Ecological Monographs 62:189222.

Strauss, S. Y., J. A. Rudgers, J. A. Lau, and R. E. Irwin. 2002. Direct and ecological costs of resistance to herbivory. Trends in Ecology and Evolution 17:278-285.

Tegner, M. J., and P. K. Dayton. 1987. El Niño effects on southern California kelp forest communities. Advances in Ecological Research 17:243-279.

Van Alstyne, K. L., M. N. Dethier, and D. O. Duggins. 2001. Spatial patterns in macroalgal chemical defenses. Pages 301-324 in J. B. McClintock and B. J. Baker, editors. Marine chemical ecology. CRC Press, Boca Raton, Florida, USA.

Williamson, J. E., D. G. Carson, R. de Nys, and P. D. Steinberg. 2004. Demographic consequences of an ontogenetic shift by a sea urchin in response to host plant chemistry. Ecology 85:1355-1371.

Womersley, H. B. S. 1996. The marine benthic flora of southern Australia. Part IIIB. South Australia Government Printing Division, Adelaide, Australia.

Wright, J. T. 2000. Population dynamics, genetic structure and evolution of chemical defenses in a marine alga. Dissertation. University of New South Wales, New South Wales, Australia.

Wright, J. T., R. de Nys, and P. D. Steinberg. 2000b. Geographic variation in halogenated furanones from the red alga Delisea pulchra and associated herbivores and epiphytes. Marine Ecology Progress Series 207:227-241.

Wright, J. T., and P. D. Steinberg. 2001. Effects of variable recruitment and post-recruitment herbivory on local population size of a marine alga. Ecology 82:2200-2215.

Wright, J. T., G. C. Zuccarello, and P. D. Steinberg. $2000 a$. Genetic structure of the subtidal red alga Delisea pulchra. Marine Biology 136:439-448.

Yates, J. L., and P. Peckol. 1993. Effects of nutrient availability and herbivory on polyphenolics in the seaweed $\mathrm{Fu}$ cus vesiculosus. Ecology 74:1757-1766.

Zangerl, A. R., and M. R. Berenbaum. 1990. Furanocoumarin induction in wild parsnip: genetics and population variation. Ecology 71:1933-1940.

Zangerl, A. R., M. R. Berenbaum, and E. Levine. 1989. Genetic control of seed chemistry and morphology in wild parsnip (Pastinaca sativa). Journal of Heredity 80:404407. 